\title{
制御系に埋め込まれた陰的制御則が適応機能の鍵を握る!?
}

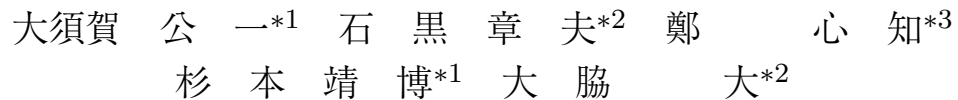

\section{Implicit Control Law Embedded in Control System Solves Problem of Adaptive Function!?}

\author{
Koichi Osuka*1, Akio Ishiguro*2, Xin-Zhi Zheng*3, \\ Yasuhiro Sugimoto*1 and Dai Owaki ${ }^{* 2}$
}

\begin{abstract}
In this note, we consider a control system that underlies in a biological system. We point out the existence of the Problem of Inseparability in the control system. To understand the principle of mobile adaptability embedded in the control system, we have to solve the Problem of Indivisibility. To solve the problem, we propose a concept of Implicit control law. Finally, we show the Implicit control law plays an important role for constructing the adaptive function of living thing and robot.
\end{abstract}

Key Words: Implicit Control Law, Explicit Control Law, Real-time Adaptive Function

\section{1. は じめに}

生物は未知な環境（無限定環境）に扔かれても適応的に行動 する（少なくとも立ち往生することなくとりあえず行動する）能 力, 環境適応能力をもっている 11$]$. あるいは多くの生物, 例え ばアリなどの社会性昆虫は時として非常に大規模な巣を作る [2]. これらはいずれも, 行動の結果を外から観察すると, 複雑な行 動生成アルゴリズムが（例えば）脳神経系にコーディングされ ているかのように見える，しかしながら，少なくとも昆虫のよ うな微小脳にはそのように複雑な行動アルゴリズムや詳細な建 築アルゴリズムをすべて記述する容量はないはずである。それ それ では, 限られた計算資源しか持たない生物が発揮するこの高度 な行動能力はどこに隠されているのだろうか？これまで，その 在処を探すために当該生物を実験室に連れて戻りその脳機能を 詳細に解析してきたが，いまだに謎は解明されていない，直感 的には何かが抜けていると思えるが，それが何かはまだ分かっ ていない.

これについて筆者らは, 生物を制御系として捉えたとき,いわ

\footnotetext{
原稿受付 2009 年 10 月 15 日

*1 大阪大学

$* 2$ 東北大学

$* 3$ 京都高度技術研究所

${ }^{* 1}$ Osaka University

*2 Tohoku University

${ }^{* 3}$ Advanced Software Technology \& Mechatronics Research Institute of Kyoto

口本論文は提案性で評価されました。
}

ゆる通常考えられる制御則（従来から詳細に解析されてきた脳 の制御機能などがそれに該当する）以外に，環境と制御対象と制 御則との相互作用によってある種の制御則が定まり，これが生物 の環境適応機能発現に大きな役割を果たしているのではないか と推察している。筆者らはその制御則を「陰的制御則（Implicit Control Law)」と呼び，それに対して従来からの制御則を「陽 的制御則 (Explicit Control Law)」と名付けている. そして上 のような環境適応能力の発現にはこの陰的制御則の存在が不可 久であり，その適応能力の理解には陰的制御則と陽的制御則の どちらかが分かればいいのではなく，両方を併せた考察が必要 であると考えている。 すなわち, これまでの研究で抜けていた のは陰的制御則であり，「生物はこの陰的制御則を活かすことが できる陽的制御則を構成しているのではないか」という仮説で ある. Fig. 1 参照. 文献 [3] [4] などで筆者らはこのような考え 方を提案し，いくつかの簡単な力学系を題材に院的制御則の例 を示している.

一方, ロボットの誕生以来, 多くの研究者らによって知能化が 追い求められ, 部分的には高度な知能（らしき能力）を実現す るに至っているが，いまだにブレイクスルーがない，やはり何 かが足りない気がする†．現在筆者らは，この不足はやはり「陰 的制御則の考慮」ではないかと考え始めている．上で述べた生 物制御系に挹ける陰的制御則と陽的制御則の考え方は, きっか けは確かに生物の制御系を考えるところから生まれたものであ

\footnotetext{
†知能にも様々なレベルの議論がありすべてを統一的に扱うことはまだ困 難なので, ここでは行動・運動レベルの話に絞っておく
} 
We have studied very well.

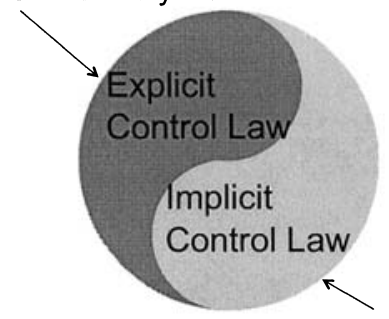

We have not studied.

\section{Real-time Adaptive Motor Function to Environment}

Fig. 1 Explicit and implicit control law

るが，実は考えている対象が生物であろうが人工物であろうが, 環境に対してリアルタイムに適応的行動を発現させたい（発現 している）対象物であれば同様に成り立つ考え方に違いないと 思っている，なぜなら，運動レベルでみれば生物もロボットも 同じ力学系であるとみなせるからである.

以上から本稿では, 文献 [3] [4] の内容を精緻化することを目 指しながら，生物制御系に埋め込まれた陰的制御則の考え方を 紹介し，それが生物には限らずロボットのリアルタイム環境適 応機能の実現に重要な役割を果たすのではないかというストー リー展開を試みる。

本稿の章構成は次のとおりである，2 章では，生物を制御系 として捉えようとするとすぐに直面する問題点である不可分問 題を紹介する． 3 章では， 2 章であげた不可分問題への一つの 攻略法として埋め込み問題を定義し，その一つの解として陰的 制御則を考える.4 章では, 陰的制御則が生物におけるリアル タイム環境適応機能発現の鍵を握っていることを示し, その結 果はロボットに扔いても同様であることを示す。そそして, 最終 章では本稿をまとめる，付録には，本稿を執筆するに当たって 筆者らが常日頃考えている考え方を参考のため揭示しておく.

\section{2. 生物制御系と不可分問題}

本章ではまず，本稿で取り扱う「リアルタイム環境適応能力 (このような能力を「移動知」と呼ぶこともある†．本研究ではそ のような能力のうち, 特に運動にかかわるレベルを考察する)」 の定義をする. そして, リアルタイム環境適応能力を解明するた めに生物を制御系と見なすとどのように見えるかを考え, 不可 分問題を定義する。これが後に陰的制御則を考える動機になる.

\section{1 生物の観察}

筆者らは「リアルタイム環境適応能力」を次のように定義する 定義 1 リアルタイム環境適応能力問題：運動能力を有してい る生物は, 無限定環境下においてリアルタイムに自らの行動を 適応させることができる。このような適応的行動能力を（動く ことで生じる身体, 脳, 環境の動的な相互作用によって発現さ れるものと捕らえ),「リアルタイム環境適応能力」と呼ぶ。そ して,リアルタイム環境適応能力の発現意義, メカニズム, 設

\footnotetext{
†「移動知」とは科学研究費特定領域「身体・脳・環境の相互作用による 適応的運動機能の発現一移動知の構成論的理解—」の中で作られた新 しい名前である $[1]$.
}

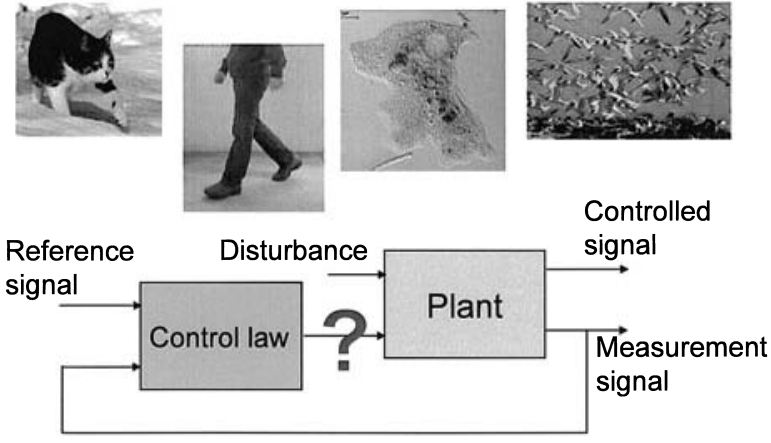

Fig. 2 Control system and living things
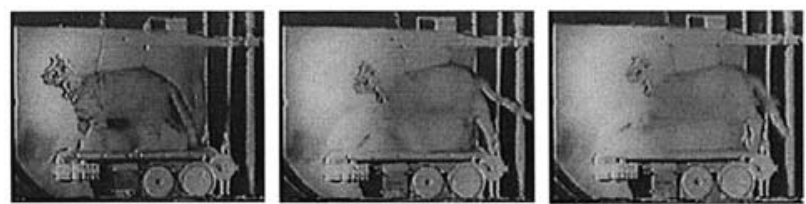

Fig. 3 Decereblated cat (T.G. Brown, 1939) [5]

計原理，解明方法などを理解する問題を「リアルタイム環境適 応能力問題」と呼ぶ.

さて，何らかの秩序だった動きをする生物には制御系が構成 されていることは確かであろう，そこで，生物を Fig. 2 のよう に制御工学におけるブロック線図で表現しようと試みてみると, 果たして眼前の生物において「どこが制御対象でどこが制御則 なのだろうか？」という疑問がすぐに湧いてくる.

例えば，人間や猫などの哺乳類は，筋骨格系が制御対象で脳 神経系が制御器（すなわち制御則）だとみなすこともできそう である。しかしながら，一方では，筋肉や神経系の中にも様々 なフィードバック系が構成されていることも知られており，そ れらは制御則の一部になるのだろうかならないのだろうか, と いうことが気になりはじめる。ささらに、アメーバーや粘菌，ナ マコなどの生き物は, 逆に, 制御対象と制御則を明確に区別で きないことは明らかであろう.

このような疑問は, Fig. 3 のようにトレッドミルの上に置か れた猫の実験 [5] をみるとより深まる。この猫は, トレッドミ ルの速度に応じて歩行パターンを変化させる能力を有している. すなわち，トレッドミルの速度が遅いときはウォークという歩 行パターンで歩き，少し早くなるとトロットになり，より早く なるとギャロップになる。この説明ではなんら驚くべきことは ないが「実はこの猫は除脳ネコである」と言われたらどうだろ うか？すなわちこの猫は，常識的には制御則であるとされる 大脳が除去されているのである。，それにもかかわらず，ある種 の環境適応能力（地面の移動速度に応じて歩行パターンを変化 させる）を有していることを本実験は示唆している，その理由 の有力な説明の一つとして, 残留神経系の中に CPG (Central Pattern Generator）が構成されており，それが歩行パターン の変化を生み出している, という説がある. 確かに $\mathrm{CPG}$ は大 きな効力は果たしていると考えられる。

しかし, 近年, (脳神経系がまったくない) 4 脚受動的動歩行 の存在が実験で示された $[6]$ ，そして，本機のシミュレータによ 
ると傾斜面の変化に応じて歩行パターンが変化するシミュレー ション結果が得られている.すなわち, 脳神経系がなくても, 身 体のみで上に見た除脳ネコと同様の行動が発現する可能性を示 している. 加えて, 従来から 2 脚の受動的動歩行の存在性 [7] と 分岐現象 [8] や安定解析 [9] [10], 成長に対する適応性 [11] など は報告されており, さらには， 2 脚の受動的走行のシミュレー ションや実験によってその存在性が示されてきている [13] [14].

\section{2 不可分問題}

前節でみた結果は, いわゆる「制御則がなくても」歩行や走 行が実現可能であり,「ある種の環境・身体適応能力を有してい る」ことを示唆している. 一方では, 意味のある運動を行って いるのであるから，「何らかの制御則が存在している」とも考え られる。

以上のように，生物の制御系をあらためて考え，そこから思 いを巡らせてみると, 制御系における制御対象と制御則の境界 が不明瞭になり,さらには制御対象と環境との境界も果たして 明確に区別できるのだろうかという疑問が湧き出てくる. とこ ろがよく考えてみると, 生物は（人工物とは違って）はじめに 制御対象が用意されて，そこに制御則が装着された結果制御系 が構成されたわけではなく, 同時発生的に制御系が構成されて きたはずなので, これら三者（制御対象, 制御則, 環境) が区 別できないほうがむしろ自然であることを思い出す [16]. した がって, これら一見相容れない考え方を組み込んで生物制御系 をブロック線図で表現しようとすると, Fig. 2 ではなく Fig. 4 のようになるという結論が導かれる.

さて, このような議論をより深く進めるにあたって, 議論展 開が不明確にならないためには, 制御対象や制御則などの用語 を改めて定義しておかねばならない.そしてそのためには, 定 義の起点として，その対象物を注目している「主体とその意図」 の存在を仮定することからはじめよう†。詳細な検討は付録 $\mathrm{A}$ で記述しているが, 多くの人工物の場合, 主体はその人工物の 設計者や使用者になる。あるいは生物の場合, 主体はその生物 に興味がある解析者, あるいは自然界（あるいは遺伝的に発現 する本能）であるとみなそうということである，また，考える

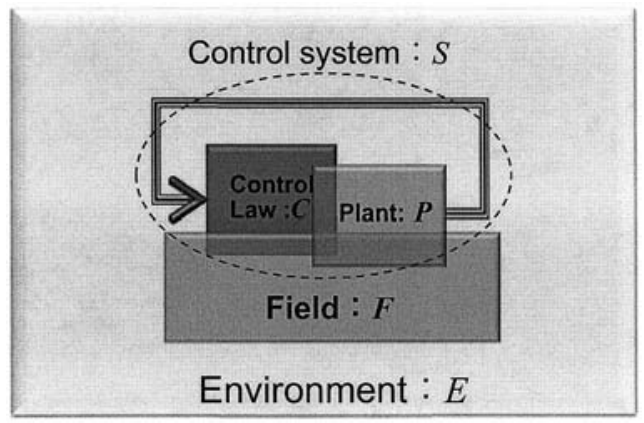

Fig. 4 Control system of living thing (2)

\footnotetext{
†ある意味で主観的なこの考え方は, 本研究が工学的観点からの考察を行 おうというスタンスにたっているから生まれるものである。すなわち, 制御対象や制御則という単語には暗黙のうちにそれらを見ている主体の 存在が想定されている，ということである。 また, これらの単語の定義 は，循環的になることからどこかを起点としなくてはならず，本研究で は主体とその意眓からはじめることにした。
}

レベルによっては，ここで注目している運動制御系よりも上位 に構成されている情報処理系（例えば脳など）が主体と考えた 方がいい場合もある (付録 $\mathrm{B}$, 付録 $\mathrm{C}$ 参照).

上のような準備のもとで，まず，すべてが含まれている空間 全体を「環境：E (Environment)」としよう。そのなかに, 主 体の「意図（あるいはそれによって生成された運動目的）：T (Task)」が存在し，それに従って運動させたいと意図されてい る考察の対象が存在しているとする.

このとき，その対象のことを「制御対象：P (Plant)」と呼 ぶ.すなわち

$$
P=\mathcal{P}(T)
$$

である，本稿では，制御対象は意図 $T$ があってはじめて意味が 生まれるものという立場をとっている.

そして, 環境の一部分であって制御対象 $P$ を内包し, かつ, 特にいま注目している意図 $T$ に直接関連し，その意図の達成に 効果的に働く集合が存在する場合，それを「場：F (Field)」と 定義する. 環境 $E$ は主体とその意図 $T$ とは無関係に存在して いるが, 場 $F$ は意図 $T$ や制御対象 $P$ に依存して存在・不存在 が定まることがあり，あるいは，物理的には存在していても意 図 $T$ に因って場 $F$ としての意味が表出したり消失したりする と考えている。すなわち

$$
F=\mathcal{F}(E, T, P)
$$

である，上式における $T$ や $P$ の寄与度は場合によって異なる. またいうまでもなく, 環境 $E$ の変化に応じて場 $F$ も変化する. 例えば，ある状況下における重力場やフェロモン場などはここ でいう場 $F$ の例になり得る. すなわち, 重力は制御対象 $P$ や 意図 $T$ に無関係に存在するが（その段階では環境 $E$ と見なせ る)，そこに意図 $T$ が入ると場 $F$ として働くことがある（後 の例参照)。また厳密に言うと制御対象の存在によって重力場は 変化する。ただし，普通は微少でありその影響は無視する。

次に, 意図 $T$, 場 $F$, 制御対象 $P$ が存在する中で, 制御対 象 $P$ を意図 $T$ にそって運動させるのに有効に働く要素がある 場合，それを「制御則 $C$ (Control Law)」と呼ぼう。すなわち

$$
C=\mathcal{C}(T, F, P)
$$

である。

最後に, 場 $F$, 制御対象 $P$, 制御則 $C$ を合わせた全体を「制 御系 $S$ (Control system)」と呼ぶ. すなわち

$$
S=\mathcal{S}(F, P, C)
$$

である。

また，制御対象 $P$ や制御則 $C$ は固定的ではなく時間ととも に変化することも念頭におくものとする，いわば，Fig. 4 は生 物制御系のある時間近傍のスナップショットを表していると見 なす。そして, 環境 $E$ はどのような場面でも存在する要素（全 体集合）なので基本は省略して, 以後は場 $F$ のみを明示するこ ととする

ここで，上のような状況を鑑みて「不可分問題」を定義して おく. 
定義 2 不可分問題：ある制御系において, 制御則と制御対象 や場の境界や役割分担が必ずしも明確ではない（ように見える） とき, これを「不可分問題」と呼ぶ.

もちろん, Fig. 4 のように複数要素間で重なって見える部分 はどちらかの要素に属しているものだと考えれば, 従来的なブ ロック線図で表現することは可能であり, 実際, これまではそ のようにしてきた。 その結果, 制御系としての振る舞いについ ての考察は十分可能であったと言えよう。しかしながら, 筆者 らは図中の制御則全体の構造や機能あるいは設計原理を知るこ とを第一の目的としているので，そのような捉え方では不十分 であり，そこに次で定義する「埋め込み問題」を考察すること の必然性が生まれる, というのが筆者らの考え方である.

\section{3. 陰的 制 御 則}

本章では，前章であげた不可分問題への一つの攻略法として埋 め込み問題を定義し，その一つの解として陰的制御則を考える.

\section{1 重なりの捉え方}

生物制御における不可分問題には様々な様相があり, 制御対 象，制御則，場の三者がほぼ分離できていると見なせる場合か ら，実質的に融合して事実上分離は不可能にみえる場合までと 広いスペクトルを有していると考えられる。本章では，このよ うに定性的な状況を定量化する工夫をについて考察する。ポイ ントは「重なっている」という定性的な感覚をどう捉えるかで ある。

例えば，前章の除脳猫をはじめとして，生物の運動にはし ばしば脳神経系の寄与が小さいと考えられるものがみられる。 その最も極端な例として捉えられる受動的ロコモーションや, R.Pfeifer らが提案している Morphological computing などの 研究結果 [17] などを外挿すると, 制御系からいわゆる制御則を 取り除いてもまだ何らかの意味の制御則（らしきもの）が残っ ているのではないか, という類推が得られる.

筆者らは，前章でみたいくつかの事例を考察し発展させた結 果, この「要素間の重なり」をそれらの間に「制御則的な働き を果たす何らかの要素が挟み込まれている」と捉えることで形 式的に分離することが一つの有効な考え方であろうという推察 を得るに至った。すなわち, 不可分問題を考察するための一つ の考え方として，Fig.5 の左のようにみえる制御系を同図右の ように見なすことを提案している [3] [4].

\section{2 埋め込み問題と陰的制御則}

以上のような考察から, 次のような問題を定式化する.

定義 3 埋め込み問題：意図 $T$, および制御対象 $P$. 制御則 $C$. 場 $F$ の相互作用によって制御系内になんらかの意味の制御 則とみなせる第 4 の要素が生まれ存在する (Fig. 5 参照) 可能 性を明確にする問題を「埋め込み問題」と呼ぶ. また, 埋め込 み問題を解くとは，(i) そのような要素が制御系内に埋め込まれ ているかどうかを明確化し, (ii) もしも埋め込まれているならば どのようなものか，という問に対する解を示すことである。

そして，もし何らかの制御則が埋め込まれていると見なせる ならば，その部分の制御則を次のように定義しよう.

定義 4 陰的制御則と陽的制御則：意図 $T$, 制御則 $C$ と制御 対象 $P$ あるいは場 $F$ との相互作用の結果, 制御対象や場に依

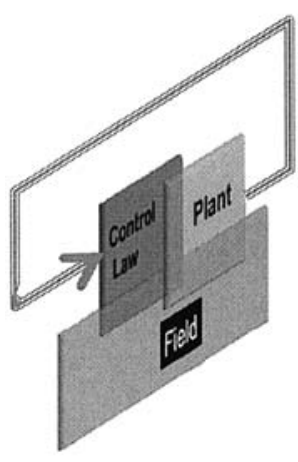

(a) Overlapping?

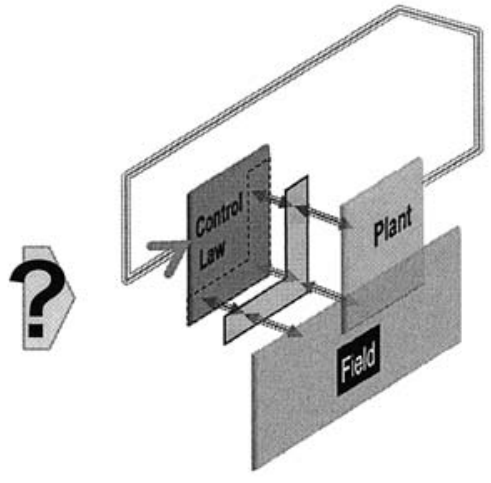

(b) Something exists?
Fig. 5 Overlapping or something exists?

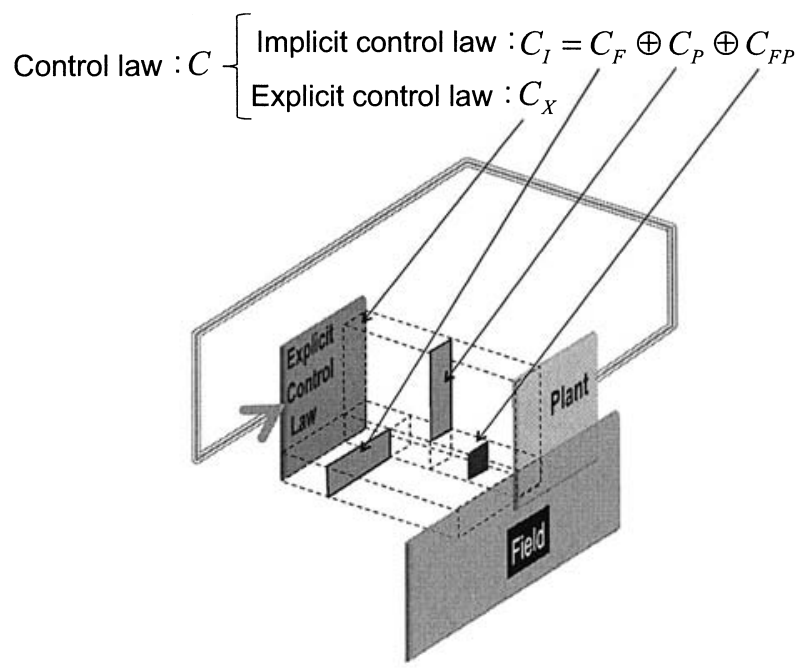

Fig. 6 Structure of implicit control law

存したある種の制御則が存在するとみなされるとき，その制御 則を「陰的制御則 $C_{I}$ (Implicit Control Law)」と呼び, 制御 則から陰的制御則を除いたものを「陽的制御則 $C_{X}$ (Explicit Control Law)」と呼ぶ.すなおち, 制御則 $C$ (Control Law) は陰的制御則と陽的制御則の合成で構成される。次式参照.

$$
C=C_{X} \bigoplus C_{I}
$$

演算 $A \oplus B$ は要素 $A$ と $B$ との間に共通要素がないとしたと きの複合を意味するものとする

さらに，形式的に陰的制御則は次のように三つの部分制御則 の合成で構成されると考える（Fig. 6 参照）.

$$
C_{I}=C_{F P} \bigoplus C_{P} \bigoplus C_{F}
$$

ただし，

$C_{F P}=\mathcal{C}_{\mathcal{F P}}(T, F, P) \quad$ : 「場 - 制御対象依存」陰的部分制御則 $C_{P}=\mathcal{C}_{\mathcal{P}}(T, P) \quad$ :「制御対象依存」陰的部分制御則

$C_{F}=\mathcal{C}_{\mathcal{F}}(T, F) \quad$ : 場依存」陰的部分制御則

である

除脳ネコや粘菌，アメーバなどをみると，陽的制御則がなく ても（あるいは効果が小さくなっても）ある種の運動が実現で 
きているようにみえる。 また, 生物から脳神経系を完全に除去 した（すなわち，完全に陽的制御則がない）ものとみなせる受 動的動歩行に関する様々な結果をみると, 陰的制御則は確かに 存在しているように思える。一方で, これらの運動は単なる非 線形力学的現象であり, それ以上でもそれ以下でもないという 捉え方も成立する。確かにそういう側面もあるが，筆者らの目 標は単に生物運動の説明ではなく, 上で定義した陽的制御則の 設計原理を理解したいということである。 そのためには, 眼前 の挙動を単なる力学現象としてひとまとめにして理解するより も，そのなかに㓌的制御則を見いたして陽的制御則はそれを活 用すると考えたほうが生物制御の理解へとつながるだろうと考 えている。

\section{3 陰的制御則の特解}

これまでの議論から, 生物制御を考える際のターゲットを絞っ てきて，その第一歩が陰的制御則を押さえることだと分かって きたので，本章ではこの陰的制御則について考察する.

陰的制御則を一般的に求めることはまだできていないが，あ る特殊な場合の陰的制御則を例示することからはじめる。いわ ば,「特解」の候補を示そうということである, 現段階では, 何 らかの特解を示すことで, それを含む「一般解」も存在するに 違いないという推測 (期待) を持っているということである.

Fig. 7 参照. いわば, 一般解の発見に向けての第一歩としての 必要条件を求める試みに相当するである.

特解を求める方法の一つとして考えられるのは, 考察の対象 に分解や解剖学的操作などを施すことなく, 何らかの場におけ る有意味な運動を実施することでフィードバックループが消え (フィードフォワードになり)，陽的制御則が見えなくなる（制 御入力が 0 になる）状況を作りだすことである，逆に，そのよ うな状況を生む意味のある運動が見つかれば具体的な陰的制御 則が見つかるということである。そのための運動が満たすべき 条件は次のようなものである.

定義 5 運動条件：次の二つの条件を満たす運動を開ループ非 干涉化運動と呼ぶ.

（1）その運動が意味のある運動であること（現実的な状況での 運動).

（2）その運動自体が安定であること（すなわち入力を 0 で実現 可能).

本節では上の運動条件を満たすある種の運動を考え, 陰的制 御則の具体例を二つ示す [3] [4]. ただしここでは, 適応機能の 前提となる安定化機能について考える。一つ目の例（マニピュ レータ）は非常に単純であるが, リアルタイム環境適応能力問 題の本質が含まれており考え方の理解の基本になるものである.

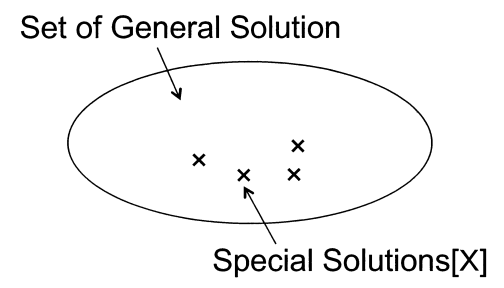

Fig. 7 General and special solutions
二つ目の例（受動的ロコモーション）は，よりリアルタイム環 境適応能力問題の一般解に近いと考えられる例で, 第一の例よ りも適応機能というニュアンスが見える.

\subsection{1 マニピュレータの姿勢制御}

まず最も単純ではあるが，陰的制御則の考え方を説明するの に有効な例をあげる。

いま Fig. 8 左上のように, 重力場（重力加速度を $g$ とする） におかれた腕（以下一端拘束された $n$ 自由度マニピュレータと する）の姿勢制御問題を考える。この場合の「場 $F 」 は$ 重力場 である、ただし，簡単のため関節はすべて回転関節で紙面に垂 直方向に回転軸があり, 関節にはクーロン摩擦項はなく, すべ ての関節にトルクを加えることができるものとする．また自由 空間の運動を考える.

この問題の範囲で上の条件を満たす運動として, Fig. 8 右上 のように「意図 $T$ : 鉛直下向きに姿勢を制御する」ことが考え られる。

実際，鉛直下向きの姿勢制御は現実的な姿勢制御問題であり， しかも直観的に鉛直下向きは重力によって安定になるため, 先に あげた運動条件を満たしている. 以下，これを確認して本ケース における陰的制御則を明示する。すなわち埋め込み問題を解く.

まず，本マニピュレータの運動方程式を書くと

$$
J(\theta) \ddot{\theta}+c(\theta, \dot{\theta})+B \dot{\theta}+h(\theta, g)=u
$$

となる。ここで, $\theta=\left[\theta_{1}, \theta_{2}, \cdots, \theta_{n}\right]^{T}$ は関節角度べクトル で Fig. 8 右上のような鉛直下向きになったところを $\theta=0$ とする. また, $u$ は $n$ 次元入力トルクベクトル, $J(\theta)$ は慣 性行列, $c(\theta, \dot{\theta})$ は遠心力・コリオリ力, $B \dot{\theta}$ は粘性摩擦力項, $B=\operatorname{diag}\left[B_{1}, B_{2}, \cdots, B_{n}\right]$ は各関節に存在する粘性摩擦係数. $h(\theta, g)$ は重力項であり, $h(\theta, 0)=h(0, g)=h(0,0)=0$ を満 たしている.

このとき，次の結果が得られる.

結果 1 マニピュレータの姿勢制御問題における陰的部分制御 則 $C_{P}, C_{F P}$ は

$$
C_{P}: u_{P}=-B \dot{\theta}
$$

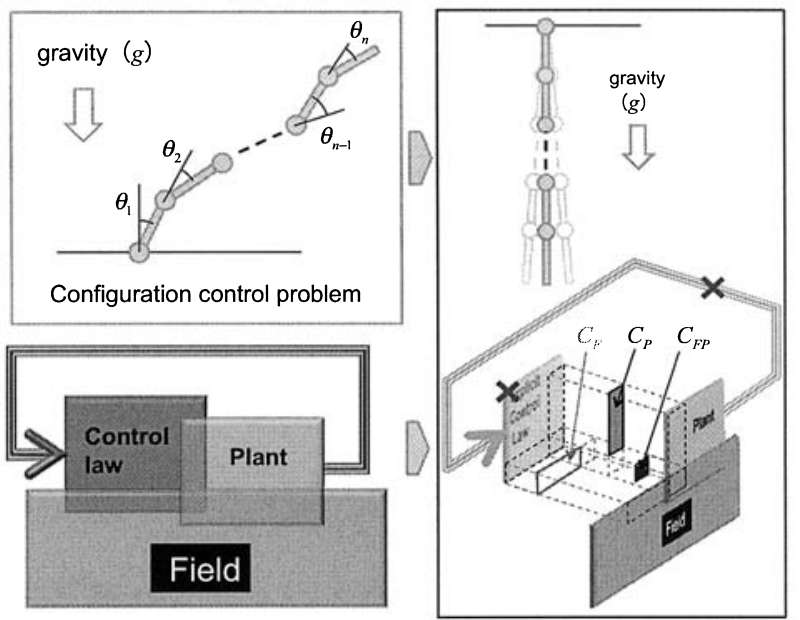

Fig. 8 From closed loop system to open loop system 


$$
C_{F P}: u_{F P}=-h(\theta, g)
$$

である. Fig. 9 参照.

証明) マニピュレータ (7) に打いて, 目標姿勢を $\theta_{d}=$ $[0,0, \cdots, 0]^{T}=0$ とすれば, $u=0$ のとき $\lim _{t \rightarrow \infty} \theta(t)=\theta_{d}$ となる。この事実に対する証明から (例えば文献 [18] 参照), $u_{P}$ は状態の漸近安定性を生み出しており， $u_{F P}$ は，マニピュレー 夕の姿勢を目標姿勢に制御していると見なせる。またこの場合 には $u=0$ なので陽的制御則はない，さらに， $u_{P}=-B \dot{\theta}$ は 重力加速度 $g$ の変化に対しては不変であり, $u_{F P}=-h(\theta, g)$ は重力加速度 $g$, マニピュレータの物理パラメータによっても 変化する。 そして, $u_{P}$ と $u_{F P}$ は意図 $T$ に沿った効果を発生 しており，したがってこの場合の重力場は場 $F$ となっている. 以上の考察と, $C_{P}$ と $C_{F P}$ の定義より, 式 (8) は制御対象依 存の陰的部分制御則に, 式 (9) は場・制御対象依存の陰的部 分制御則になっていると分かる。いずれも，いま考えている意 図 $T$ に有効に働くので陰的制御則とみなしている点に注意さ れたい.このことは逆に言うと, 意図 $T$ に応じては同じ要素で も制御則にも外乱にもなり得ることを意味している。 また場 $F$ についても同様で, ここで考えた意図 $T$ の場合には重力場が場 $F$ になっている，ということである。

上の例では，三つの陰的部分制御則のうち， $C_{P}$ と $C_{F P}$ を 例示したが， $C_{F}$ については触れなかった。この陰的部分制御 則は陽的制御則 $C_{X}$ と場 $F$ との間に生まれるとしている。し たがって，この陰的部分制御則を有する個体には必然的に陽的 制御則の存在が要求される。すすなわち, 素朴な意味で高度な運 動制御能力を有していると考えるべきであろう。また具体的に は，場とのやり取りを力学的相互作用で行うのではなく，情報 的相互作用で行っていると考えなくてはならないかもしれない. これについてはまだ十分な考察ができていないが，矢野らのみ なし情報 [19] の生成に梁く関連しているように思われる.今後 の課題である.

\subsection{2 受動的ロコモーション}

人類の歩行問題に掞ける陰的制御則は存在するならばどのよ

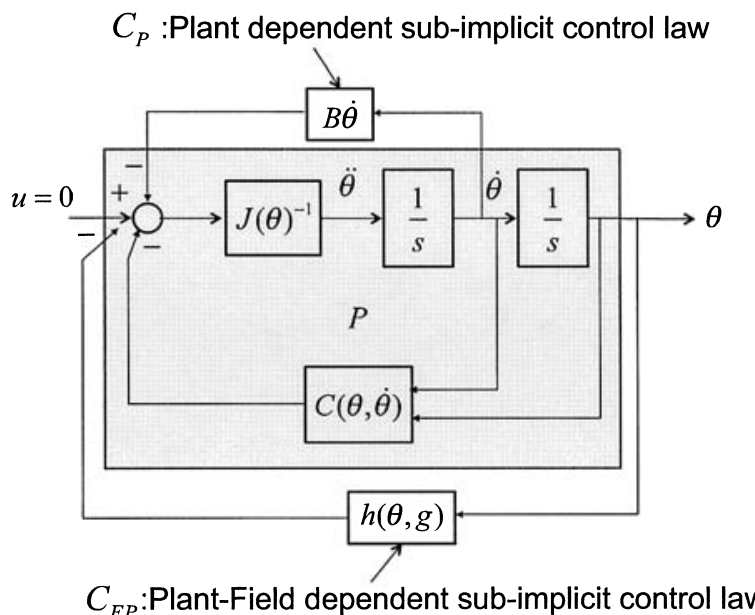

Fig. 9 Two implicit control law in manipulator configuration control problem
うなものになるのだろうか.この問題の範囲で運動条件を満た す運動として, Fig. 10 中央のように「傾斜面を歩行する状況 を考え，それをさらに単純化した受動的動歩行」が考えられる。 なぜなら，（1）受動的動ロコモーションは傾斜面に拀ける歩行 という現実的な状況であり，（2）しかもこれまでの知見からこ の現象は安定であることが示されてきているため，先にあげた 運動条件（1）（2）を満たしているからである，以下，この場合 の陰的制御則がどのようなものになるかを確認しよう。まず， 2 脚の受動的動歩行は Fig. 11 のようなコンパスモデルで表現さ れる。

そして, 詳細は省略するがいくつかの仮定のもと, 着地点に 注目すると本システムは次式のような離散力学系として表現す ることができる。

$$
\Delta x_{k}=\mathcal{P}_{k}\left(\Delta x_{k-1}\right), \Delta x_{k}=x_{k}^{-}-x_{*}^{-}
$$

ここで, $x=\left[\theta_{p}, \theta_{w}, \dot{\theta}_{p}, \dot{\theta}_{w}\right]^{T}, x_{k}^{-}$は第 $k$ 歩目の着地直前の状 態， $x_{*}^{-}$は定常的に歩行しているときの着地直前の状態, $\mathcal{P}_{k}(\cdot)$ は $\Delta x_{k-1}$ を $\Delta x_{k}$ に写像する非線形な関数を要素にもつ非線 形写像である。このようなモデルを用いると, 受動的動歩行が 安定に歩行することは式（9）において原点が安定であることに 対応する，そこで，安定解析を行うために本式を原点近傍で線 形化すると次式が得られる（ブロック全図で描くと Fig. 12 (a) のようになる).

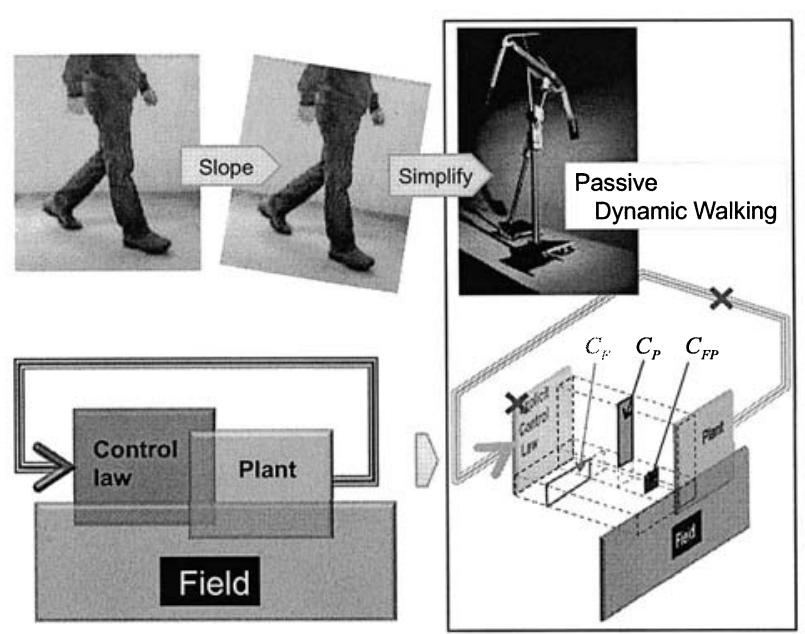

Fig. 10 From closed loop system to open loop system (2)

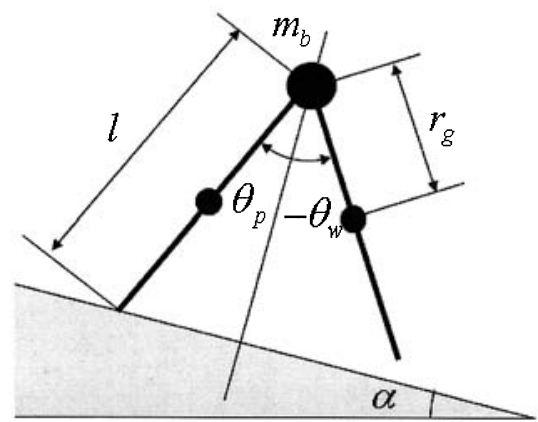

Fig. 11 Compass model of passive dynamic walking 


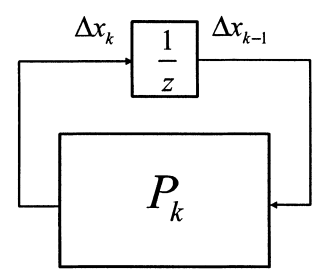

(a) Passive dynamic walking as a Discrete Dynamical System

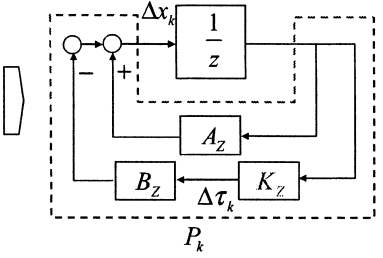

(b) Internal structure of liberalized Poincare Map
Fig. 12 Implicit control law in passive dynamic walking

$$
\Delta x_{k}=P_{k} \Delta x_{k-1}
$$

ただし， $P_{k}$ は線形化ポアンカレ写像で,

$$
P_{k}=\left(I-\frac{\nu_{*} C}{C \nu_{*}}\right) \exp \left(A \tau_{*}\right) R_{d}
$$

と書かれる。ただし, 本式中の変数や行列は以下のように求め られる。

まず， $A, b$ は，本システムが片足支持状のときの運動方程式を $x=0$ において線形近似することで得られ， $\nu_{*}$ は, $\nu_{*}=A x_{*}^{-}+b$ である. また, $R_{d}$ は遊脚の斜面への衝突による脚の切り替え を表現する切り替え方程式（角運動量保存則を用いる）

$$
x^{+}(t)=R\left(x\left(^{-}(t)\right)\right.
$$

から得られる $R(x)$ を用いて

$$
R_{d}=\left.\frac{\partial R(x)}{\partial x}\right|_{x=x_{*}^{-}}
$$

と計算される．最後に，Cは脚が斜面に拘束されることを表現 する拘束方程式

$$
C x(t)=0
$$

から得られる.

このとき, 次の結果が得られる.

結果 2 ある歩行問題における陰的部分制御則 $C_{F P}$ は

$$
C_{F P}: \Delta \tau_{k}=-K_{z} x_{k-1}
$$

である、ただし， $K_{z}$ は本システムの物理パラメータや重力加 速度，傾斜角などから定まるフィードバックゲインである $[9]$.

証明）紙面の制約上詳細は省略するが（文献 [9] 参照）, 計算過 程で

$$
\begin{aligned}
\Delta x_{k} & =A_{z} \Delta x_{k-1}+B_{z} \Delta \tau_{k} \\
\Delta \tau_{k} & =-K_{z} \Delta x_{k-1} \\
K_{z} & =\left(C_{z} B_{z}\right)^{-1} A_{z}
\end{aligned}
$$

を得ることができる。本式はブロック線図で表現すると Fig. 12 (b) のようになる。 これは線形化ポアンカレ写像 $P_{k}$ の 内部構造に状態フィードバックが構成されていることを意味し ている. そしてこのフィードバック構造が受動的ロコモーショ ンの安定性を生んでいることが確かめられる。ささらに, 今の場
合，意図 $T$ を考えるのは我々観測者であり，本フィードバック 構造は重力加速度が 0 になったり, 脚機構を斜面から離すと消 えることから, 重力場と斜面の存在が場 $F$ になっていると見 なしている. そして, 本フィードバックゲイン $K_{z}$ は脚機構の 物理パラメータに依存している。 すなわち, 本フィードバック 則は場・制御対象依存陰的制御則 $C_{F P}$ になっていると考元ら れる。

受動的ロコモーションについては, 様々な知見が集まりつつ ある。例えば，傾斜面の角度や身体パラメー夕を連続的に変化 させたとき歩行パターンが自立的に遷移することで歩行を継続 するシミュレーション結果が報告されている [11]. これは, 受動 的動歩行にはある種の環境適応機能や身体適応機能が内在して いることを示唆している. また, 脚や胴体関節にバネを有する受 動的走行機械には美多らが提案している Two-Delay-Feedback Control [12] による Implicit Feedback Structure が内在して いることが分かってきた [13]. 受動的走行現象については実験 により存在証明もなされている [14]. さらに，4 脚受動的動歩 行 [6] や 20 脚受動的動歩行 [15] の存在も実験やシミュレーショ ンで示されて抢り，院的制御則の存在を支持する事例が集まり つつある.これらについてのさらなる理論的考察が今後の展開 として期待したい.

\section{4. 陰的制御則とリアルタイム環境適応機能}

これまで，生物制御系に㧍ける不可分問題に対する一つの解 として陰的制御則を導入してきたが，実はこの陰的制御則は， 生物が持っているリアルタイム環境適応機能の発現に対する重 要な鍵になっていると考えられる，本章では三つの陰的部分制 御則のうち, 最も環境適応機能に関係が深いと考えられる $C_{F P}$ について, 環境適応機能という観点から, 詳細に検討する.

前章の結果は限定された非常に単純な例（特解：Fig. 7) であ るが，そこでの結果は，一般的に陰的制御則が存在する可能性 を示唆するものであると考えている，以下 4.1 節では，これま での議論の流れの延長線上として, 生物がもっているリアル夕 イム環境適応機能の発現と理解には陰的制御則 $C_{F P}$ が重要な 鍵を握っているのではないかという仮説を述べる，そして，4.2 節では，その考え方が生物独特ではなく場と相互作用すること が本質的であるロボットの知能化においても同様に不可欠であ り, 従来研究では陽に定式化してこなかった点であるという考 え方を述べる。

\section{1 生物のリアルタイム環境適応機能}

$C_{F P}$ は, 以下に述べるように, 生物がもつリアルタイム適 応機能の発現に扔いて最も重要であると考えられる。これまで 直感的に,「陰的部分制御則 $C_{F P}$ は制御対象と場との相互作 用によって生まれるものである」というような表現をしてきた が, 実際, マニピュレータの姿勢制御問題においては, マニピュ レータが重力場におかれることで陰的部分制御則 $C_{F P}$ は生ま れており, 重力加速度が 0 になる（すなわち「場 $F$ 」を取り除 く）と $C_{F P}$ は消失する. また受動的ロコモーションの例でも

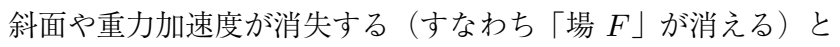
内在している安定化フィードバック構造は消える.ささら意図 $T$ が変わると，それまで場であったものが場ではなくなり別の 


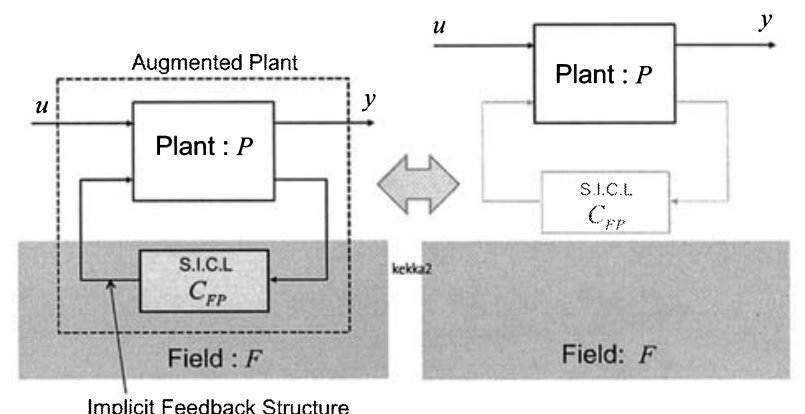

(a) If Plant and Field are interacted then Implicit Feedback Structure is constructed. (b) If Plant and Field are decoupled,
then, Implicit Feedback Structure then, Implicit Feedback Structure is disappeared.

Fig. 13 Appearance and disappearance of $C_{F P}$

場が表出する可能性もある。まとめると次のような仮説になる。 Fig. 13 参照.

- 陰的部分制御則 $C_{F P}$ は, 意図 $T$, 場 $F$ と制御対象 $P$ との 相互作用をもつことで生まれた陰的制御則であり, 場 $F$ と 制御対象 $P$ の間にフィードバック構造が生まれたことによっ て得られる。このようにして生まれるフィードバック構造を 「陰的フィードバック構造 (Implicit Feedback Structure)」 と呼ぶ.

- 陰的部分制御則 $C_{F P}$ は, 場 $F$ と制御対象 $P$ との相互作 用がなくなると消失する.

- 陰的部分制御則 $C_{F P}$ は, 制御対象 $P$ が不変であっても場 $F$ あるいは意図 $T$ がリアルタイムに変化すると, それと ともにリアルタイムに変化する.

- 陰的部分制御則 $C_{F P}$ は, 無数に存在する場 $F$ と制御対象 $P$ との関係を集約して表現されたものである.

これまでの考察を総合すると, 生物が持っているリアルタイ 厶環境適応機能に対する次のような筆者らの考え方が得られる.

まず，何らかの意図 $T$ を持った（あるいは与えられた）生物 を想定する。このとき, この生物を取り巻く環境 $E$ は様々な要 因で変化する (環境そのものの変化もあれば生物が移動するこ とによって生物から見た環境が変化することもある)，それに対 して生物は，その変化に対応して自分自身全体が意図 $T$ に沿う ように, 制御系内に何等かの調整機構を内蔵させていると考え られる。 もしそうであるなら, その調整が可能なのは設計の自 由度が許されている陽的制御則 $C_{X}$ であるという考察が導かれ る。 なぜなら, 陰的制御則 $C_{I}$ は場 $F$ や制御対象 $P$ などに依 存した拘束がかけられているので直接的な設計はやりにくいと 考えるからである（ただし，意図 $T$ によって間接的に設計可能 な場合もある)。

次に, 環境 $E$, 意図 $T$, 制御対象 $P$ が存在し, それらの相 互作用によって場 $F$ と㓌的制御則 $C_{I}$ が表出され, その設定 に拀いて何らかの陽的制御則 $C_{X}$ が構成されており，全体とし てある秩序状態になっている状況から考えよう。そのとき，環 境 $E$ に変化があった場合，その変化がどのように波及していく かを考察してみる（意図 $T$ は変化しないとしておく）。環境 $E$ の変化は, 場 $F$ の変化を生み, それと連動して陰的部分制御 則 $C_{F P}$ の変化を誘導させる. 生物の目標が常に自分自身を意

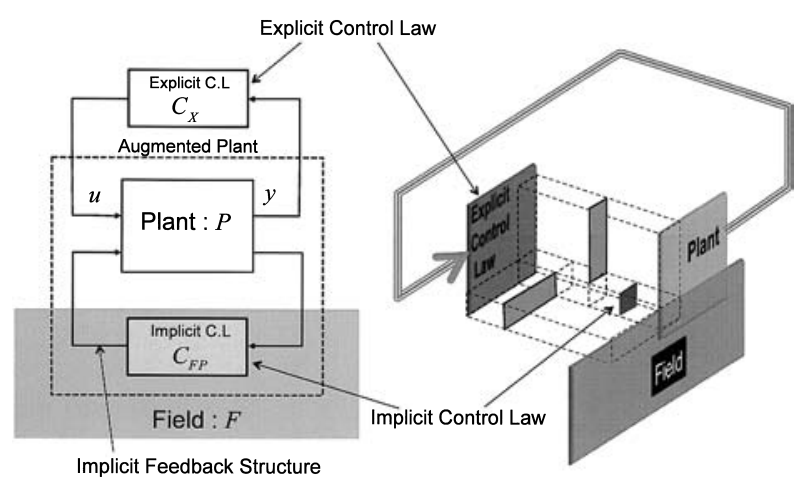

Fig. 14 Explicit control law and implicit control law

図 $T$ に沿うように行動させることだとすると, 環境 $E$ の変化 は, 当初設定されていた陽的制御 $C_{X}$ の不整合性を生む. すな わち，意図 $T$ に沿わない行動になってしまうことを意味する. そのため, 意図 $T$ に沿うためには, 生物の陽的制御則 $C_{X}$ は 陰的部分制御則 $C_{F P}$ の変化にリアルタイムに適応的に対処で きる能力を兼权備えて扔く必然性が生まれる。この対処は「繰 り返し学習」では対応できない，なぜなら場 $F$ の変化がリアル タイムになっており, 同じ場 $F$ が続かないことを前提に考察し ているからである。

その調整は, 環境 $E$ の変化を反映している陰的制御則 $C_{F P}$ を併せた制御則 $C$ が制御系全体を力学的に合理的になるよう になされると推察される．以上から次の結論を明示しておく。

結論 1 リアルタイム環境適応機能 : 生物が持っているリアル タイム環境適応能力を以下のように理解する.

存在 生物のリアルタイム環境適応機能創出の必然性は陰的部 分制御則 $C_{F P}$ の存在性からきている.

機能 生物のリアルタイム環境適応機能とは, 時々刻々変化す る場に応じて変化する陰的部分制御則 $C_{F P}$ を有効活用す ベく陽的制御則 $C_{X}$ をリアルタイムに適応させる能力であ る. Fig. 14 参照.

理解 生物のリアルタイム環境適応機能を理解するには, 陽的 制御則 $C_{X}$ と陰的制御則 $C_{I}$ を併せた理解が必要である. その際，陰的制御則 $C_{I}$ は場を切り離しては議論できないた め, 生物を場から切り離してその個体の制御能力を解明し ても，それは $C_{X}$ のみの理解にとどまり，望んでいるリア ルタイム環境適応能力の理解には到達しない. Fig. 1 参照.

生物のリアルタイム環境適応機能を理解するには陰的制御則 と陽的制御則の両方の理解が必要であることを論理的に導いて きたが，その意味では，従来からのこの分野に扮ける研究は陽 的制御則の探求に集中していたと言える.今後の課題は，「院的 制御則の実態を見極め，それに整合した陽的制御則がどのよう に設計されているかを再探求する」である。

\section{2 ロボットのリアルタイム環境適応機能}

前節までで, 生物制御系にみられるリアルタイム環境適応機 能の発現原理について考察してきた，その過程はいわゆるリバー スエンジニアリングを行っていると言えよう。その結果，陰的 制御則が定義されその役割が明示された。そしてリアルタイム 


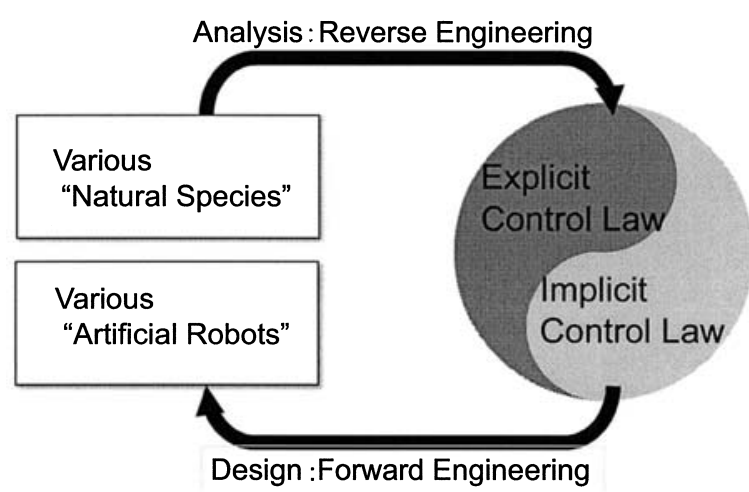

Fig. 15 Reverse engineering and forward engineering

環境適応機能を理解するためには陰的制御則と陽的制御則の両 方が不可欠であることをみてきた．Fig. 15 の上の矢印参照.

ここで注意しておきたいことは, 本研究の流れは,「生物を 模做しょうとしているのではない」ということである。議論の きっかけは生物制御系の考察であったが, ここで得られた陰的 制御則というアイデアは, 生物制御系を離れて力学系としての 考察結果になっている.このことは, 同じょうにリアルタイム 環境適応機能の実現を目指すロボットに対しても共通の考え方 になっていることを意味している。したがって，本稿で得られ た知見から、「リアルタイム環境適応機能を具備したロボットを 実現するためには，陽的制御則と陰的制御則の両方を考慮した ロボットの制御系設計が必要である」という設計指針が得られ る.すなわち, Fig. 15 の下の矢印が示すフォワードエンジニア リングである.

従来のロボット研究では, 陽的制御則の研究が重点的になさ れてきたと言えるが, 筆者らの考察が正しければ, それだけで は不十分で, 陰的制御則に関する考察を加えなくてはならない ということになる，ただし，このような考え方はなかったわけ ではなく, 有本らは「日常の物理」などと言いその重要性を指 摘している $[20]$. 本稿の主張は, そのような考え方の換言であ るとも言えるが，筆者らには㓌的制御則という考え方によって 考えるべき問題の所在がこれまで以上に明確化できたと考えて いる.もち万ん, これでリアルタイム環境適応機能が理解でき たわけではなく，それを理解するためには何を理解しなくては ならないか，が分かったという段階である，真に理解し，その 結果をロボットの設計論に適用するためには,「陰的制御則の存 在のみを仮定した陽的制御則の設計論」が確立されなくてはな らない. 今後の課題である。

\section{5. おわりに}

ノーバート・ウイナーは, サイバネティクスの中で生物と機械 に㧍ける制御と通信を統一的に取り扱うことを提案し [21], 現 代の制御工学が生まれるきっかけをつくった，それによって，生 物を制御系として捉えることができるようになり，ある意味で 生物制御の理解が進んだと言えよう。これは本問題における制 御工学的アプローチの効用である.

ところが一方では, 生物の制御系を従来の制御工学的観点か ら捉えようとすると,うまくあてはまらないことにも気づく. 例 えば，生物においては，(a) 不可分性：どこが制御対象でどこ が制御則か，あるいは環境かを特定することが難しい（場合に よってはできない), (b) 閉ループ性 : 基本的には多重閉ループ システムになっている, (c) 非定常性 : 制御対象と制御則と環境 の境界が時間とともに変化する, (d) 自己言及性：制御系に対 する目標值を内部で生成する，(e) 自己エネルギー発生性：内部 にエネルギー発生源を有しているので単純にエネルギー保存則 の考え方を単純には適用できない，など，通常の人工物の制御 系にはみられない性質（問題点）がある.

一般に制御工学では, 例えば, 制御対象と制御則は固定的で 明確になって抢り, 目標值はあらかじめ与えられることが基本 なので, 上の性質を持つ制御系の解析は通常の制御工学的アプ ローチにとって苦手である。

筆者らは, この事実が生物制御の理解に有力な方法論になり 得ると見える制御工学的アプローチに対する限界を生み, 生物 制御の理解がある一定の所で停滞していた理由の一つであると 考える.

本稿では，上にあげた五つの特徴のうち，「(a) 不可分問題」 が本問題において最も本質的であるという立場から考察を行っ た。具体的には, 生物制御系に内在する不可分問題を意識しそ の解決策として筆者らが提案している陰的制御則という考え方 を紹介した，そして，その陰的制御則が生物が持っているリア ルタイム環境適応機能を解明する際の鍵になっているのではな いかという推察を述べた，そして，実はこのような考察は生物 に限って成り立つものではなく，その本質は力学系であるとい う考えにたつと, ロボットの知能化にも共通する議論であるこ とが分かってきた，そこから前章ではロボットにリアルタイム 環境適応機能を具備させるためにはやはり陰的制御則が重要な 役割を果たすことになるという結論を導いた。

様々な動くものをみていると, なぜこんなに簡単な制御則し か内蔵されていないのに，このように合目的な作業が実現でき るのだろうか，と疑問に思うことがある。この感覚は生物でも 人工物でも味わうことがある. 特に微小脳しか持っていない昆 虫の動きなどをみるとしばしばそのように感じる，このような とき, 筆者らは, 制御対象と場の相互作用によって陰的制御則が 生まれており，それが陽的制御則を補完しているに違いないと 考えている.ロボットに対してリアルタイム環境適応機能を期 待する場合，まさに同じような問題に直面すると言えよう。い くら陽的制御則の能力を高めても昆虫のような環境適応能力が 見えてこない理由の一つに陰的制御則を考慮してこなかったこ とがあるのではないだろうか.

ここで紹介した議論はまだまだ仮説の段階（いわば必要条件 の候補を考察したにすぎない）で，今後はより多くの例題（特 解）の探索と理論解析, そして, 生物における陰的制御則の発 見を目指す必要がある.また，「場」を制御系の外と考えるので はなく，一体化して陽に考慮する制御系を考えると興味深いに 違いない。

謝 辞 本研究は, 文部科学省科学研究費補助金特定領域研 究「身体・脳・環境の相互作用による適応的運動機能の発現— 移動知の構成論的理解一」で得られた成果に基づいている.こ こに謝意を表す。 


\section{参 考 文 献}

[1] 移動知 HP : http://www.robot.t.u-tokyo.ac.jp/mobiligence/

[2] マイク・ハンセル（長野, 赤松 共訳）：建築する動物たちービーバー の水上邸宅からシロアリの超高層ビルまで，青土社， 2009.

[3] 大須賀, 石黒: “受動的ロコモーションに埋め込まれた適応機能”, シス テム制御情報学会, システム/制御/情報, vol.53, no.2, pp.711-717, 2009.

[4] 大須賀公一：“制御系に扔ける「埋め込み問題」とは? 一生物/人工物 の運動制御機能の理解に向けて—”, 計測自動制御学会, 計測と制御, vol.48, no.9, pp.493-499, 2009.

[5] T.G. Brown: Decerebrate Cat Movie, 1939, in Video: The Basal Ganglia and Brainstem Locomotor Control, by E. GarciaRill, 1989.

[6] K. Nakatani, Y. Sugimoto and K. Osuka: "Demonstration and Analysis of Quadrupedal Passive Dynamic Walking," Advanced Robotics, vol.23, no.5, pp.483-501, 2009.

[ 7 ] T. McGeer: "Passive Dynamic Walking," Int. J. of Rob. Res., vol.9, no.2, pp.62-82, 1990.

[8] 大須賀, 桐原： “受動的歩行ロボット Quartet II の歩行解析と歩行 実験”, 日本ロボット学会誌, vol.18, no.5, pp.737-742, 2000.

[9] 杉本, 大須賀： “受動的動歩行の安定性に関する一考察ーポアンカレ マップの構造解釈からのアプローチ”, システム制御情報学会論文集, vol.18, no.7, pp.255-260, 2005.

[10] 平田健太郎：“受動歩行に内在する安定化機構について”, 計測自動制 御学会 第 8 回制御部門大会資料, 053-4-3, 2005.

[11] M. Iribe and K. Osuka: "Design of the Passive Dynamic Walking Robot by Applying its Dynamic Properties," Journal of Robotics \& Mechatronics, vol.19, no.4, pp.402-408, 2007.

[12] 美多, 千田：“多大出力 2-delay ディジタル制御の提案と応用”, 計 測自動制御学会論文集, vol.24, no.5, pp.467-474, 1988.

[13] 大脇，大須賀，石黒：“受動走行の背後に潜む安定化メカニズムの解 明”, 第 26 回日本ロボット学会学術講演会予稿集 CD-ROM, 3B1-09, 2008.

[14] 小山, 山口, 大脇, 石黒 : “弾性要素を活用した受動走行の実機実現”, 日本機械学会 ROBOMEC2009, 2P1-D05, 2009.

[15] 吉岡, 杉本, 大須賀 : “超多脚型受動的動歩行ロボットの実現に関する研 究”, 日本機械学会 ROBOMEC2009, CD-ROM-2P1-D02, 1999.

[16] J. スコットターナー（滋賀, 深津 共訳）：生物がつくる「体外」構 造一延長された表現型の生理学. みすず書房, 2007.

[17] R. Pfeifer, F. Iida and G. Go'mez: "Morphological computation for adaptive behavior and cognition," International Congress Series 1291, pp.22-29, 2006.

[18] 有本卓：“巧みさ”とロボットの力学. 毎日コミュニケーションズ, 2008.

[19] 矢野, 冨田, 牧野: “随意運動のための「見なし情報」の創発”, 計測 自動制御学会, 計測と制御, vol.44, no.9, pp.590-595, 2005.

[20] 有本卓：ロボットの力学と制御。朝倉書店, 2002.

[21] ノーバート・ウイナー (池原, 彌永, 室賀, 戸田 共訳) : サイバネティッ クス一動物と機械における制御と通信一(第 2 版), 岩波書店, 1962 .

[22] 高草木薰: “大脳基底核による運動制御機構”, 日本ロボット学会誌, vol.23, no.1, pp.2-5, 2005.

[23] P.D. MacLean: The triune brain in evolution: role in paleocerebral functions. Springer, 1990.

[24] 津田一郎：カオス的脳観一脳の新しいモデルをめざして。サイエンス 社, 1990 .

\section{付録 A.「意図」について}

本文でも書いているが，そもそも「制御」あるいは「適応機 能」という言葉には何らかの意味の「主体：SB (Subject)」が 存在し， ある対象をその主体が一つ上のレベルから観ていると いう前提が想定されている。 ただしそれは必ずしも絶対的に定 まるものではなく，ちょうど起伏のある地形に扔いて等高線を 引くようなもので，あるレベルを想定するとそれより上が「主

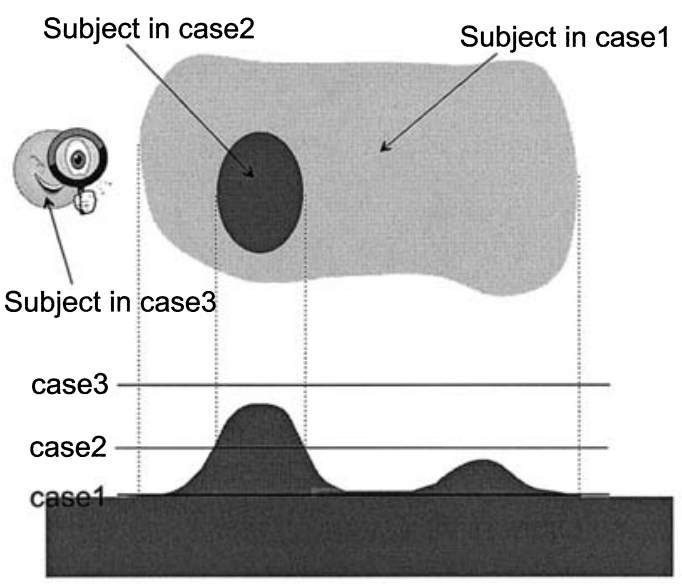

Fig. 16 Subject and plant

体」であり，それより下が「制御対象」となる，というような ものである. Fig. 16 に二瘤山を例にその概念を図示した.

まず，本来山はどこからが地面でどこからが山かの境界はな い. 境界は便宜上（この場合）人が決める。 その際，海抜 $0[\mathrm{~m}]$ 以上を山だと定義すると, $0[\mathrm{~m}]$ 以上の部分を「山」下の部分 を「地面」と区別できる， case1 である，しかしある人が海抜 $100[\mathrm{~m}]$ 以上を山だと定義すると図の case 2 のように山の中腹 から上を山，それより下を「麓」と考える，さらに第三者的に 山よりも上空から観る場合には, case3 のように山とまわり全 体を注目することになる。

上の山を生物に置き換えてみると, case3 はその生物を観察 している人が主体, case 2 は一個体の中の例えば上位脳が主体, case1 は遺伝子レベルで定められた本能が主体と考えられる. case 3 と case1 は両極端であり，ある意味で自由度はそれほど ない. case2 はどこにレベルをもってくるかで様々なバリエー ションがある。またそのレベルは時々刻々変化することもある。 例えば，最初はかなり下に設定されていたものが徐々に上に移 行するとも考えられる（これがいわゆる生物が持つ「委譲性」 である)。また運動機能に注目し，その運動を発現させる要素を 考えると, 運動制御系は制御対象になり, 上位要素は主体とな る. 付録 $\mathrm{B}$ 参照.

もち万ん，上のような考え方は生物に限ったものではない，人 工物であっても主体とその意図を考えることができ，その境界 は絶対的とは限らない。例えば, ジェームスワットの遠心調速 機付きの蒸気エンジンシステムなどがその好例である.

この遠心調速機は蒸気エンジンの回転数を自動的に調整する ためにジェームスワットが導入したものである。この装置は蒸 気エンジンと一体化して抒り，どこまでが蒸気エンジンでどこ までが調速のための部分（制御則）かが必ずしも明確ではない.

\section{付録 B.「生物がもつ階層性」について}

生物には運動を実現させるための身体系（粘菌なら流動的な, 軟体動物なら軟組織が, 春椎動物なら筋骨格系や内臓系), あ るいは処理系（様々な化学物質の授受や生成など）が存在する. そして, 脊椎動物の脳構造は Fig. 18 のように階層的になって 


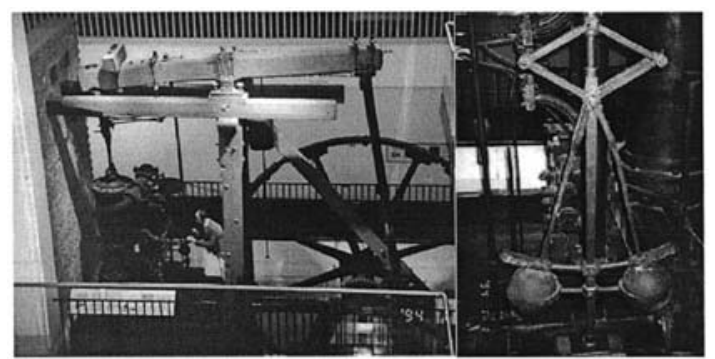

Fig. 17 Centrifugal governor

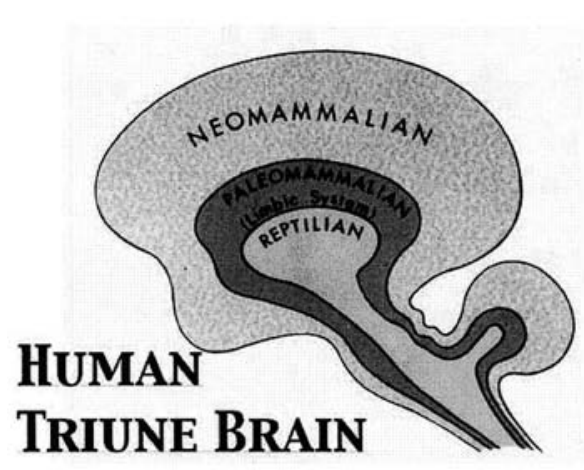

Fig. 18 Human triune brain [23]

いる。すなわち進化の過程と連動して, 古皮質（生存脳あるい は爬虫類脳 (reptilian brain)），旧皮質（情動脳あるいは旧哺 乳類脳 (paleomammalian brain)), 新皮質（創造脳あるいは 新哺乳類脳 (neomam-malian brain)) と層構造になっている と考えられている [22] [23].

この下層脳になるほど身体の運動系と直接的な関係が深くな る.さらに，高等生物では，上位脳は基本的な処理を下位脳に 委譲することを基本としているように見える。これらから筆者 らは次のようなリアルタイム環境適応能力発生における基本制 約を仮説している.

身体性：生物は力学的（物理的な動特性や化学的な反応特性） 「身体」を有する。

脳構造：脳は階層構造を有しており，上層脳は下層脳の存在を 受けて存在している。最下層脳は身体の運動系と強い連係 がある。

委譲性：上層脳は下層脳で処理できるものはできるだけ下層脳 に任せようとする傾向がある。

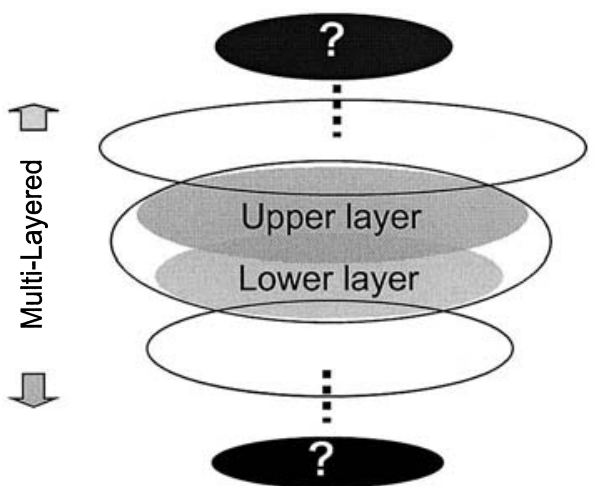

Fig. 19 Multi-layered system

また，生物では 1 個体の中でも複雑なリアルタイム環境適応 能力の表象が見られ, 様々なレベルの適応機能が階層的に併存 している。ささらに, 社会的な組織においても社会のリアルタイ ム環境適応能力が存在し，そこでも個体から小グループ，さら には種族全体というような階層的な構造が存在している。これ らのことからリアルタイム環境適応能力の存在に関して次のよ うな状況が想定できる.

複雑性：1 個体の行動においてその内部において複雑な適応機 能が存在する.

社会性：個体の行動と社会の行動の中に階層的な適応機能が存 在する。

\section{付録 C.「階層構造の最上下」について}

付録 B で生物は階層構造になっていると考えると捉えやすい ことを述べた。階層構造において中間層は階層的ということで 説明がつくが，もっとも上位ともっとも下位（いわゆる両終端条 件）を明示しておく必要がある. Fig. 19 参照. このうち「最下 位レベルは身体である」と言えるが，最上位レベルにはどのよ うな構成要素があてはまるのであろうか? 階層性は構造化さ れていると言えるので, システムがすべて階層的に構造化され ていると情報処理システムの自由度がなくなり，いわゆる（上 位）知能の入る余地がなくなるように思える。このような知能 が生まれるためには,「最上位脳は非構造化」されていなくて はならないだろう。すなわち, 脳を有している生物においては 脳で行われている情報処理系をカオス的に捉えることができよ う [24]. 


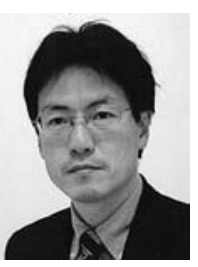

\section{大須賀公一 (Koichi Osuka)}

1984 年大阪大学大学院基礎工学研究科修士課程（制 御工学) 修了。同年 (株) 東芝入社, 総合研究所勤 務. 1986 年大阪府立大学工学部助手. その後, 講 師, 助教授を経て, 1998 年京都大学大学院情報学 研究科助教授, 2003 年神戸大学工学部教授, 2009 年大阪大学大学院工学研究科機械工学専攻教授とな り現在に至る。ロボテイクス, 制御工学, レスキュー工学などの研究 に従事. 1986 年度計測自動制御学会学術奨励賞, システム制御情報学 会椹木記念賞奨励賞, 計測自動制御学会論文賞, 2002 年同学会教育貢 献賞, 2005 年第 11 回ロボティクスシンポジア特別奨励賞, 日本機械 学会ロボティクス・メカトロニクス部門 ROBOMEC 表彰, 2007 年 同部門学術貢献賞などを受賞. 2008 年日本機械学会フェロー. IEEE, 計測自動制御学会, システム制御情報学会, 日本機械学会などの会員. 工学博士.

(日本ロボット学会正会員)

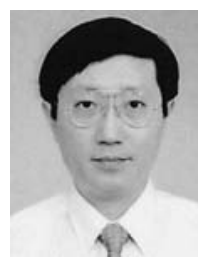

\section{鄭 心知 (Xin-Zhi Zheng)}

1994 年京都大学大学院工学研究科機械工学専攻博 士課程修了. 同年豊橋技術科学大学情報工学系助手. 1996 年東京工業大学大学院総合理工学研究科助手. 2000 年京都高度技術研究所メカトロニクス研究室 長, 2006 年同知能システム制御グループリーダー, 2007 年同研究部主席研究員, 現在に至る。その間, 1995 年理化学研究所バイオ・ミメテイックコントロール研究センター フロンティア研究員, 2001 年立命館大学大学院理工学研究科非常勤 講師, 2007 年国際レスキューシステム研究機構客員研究員などを兼 任. 京都大学博士 (工学). ロボティクス・メカトロニクス要素・シ ステム・制御技術, レスキュー工学などの研究に従事. ASME 1995 JDSMC Best Paper Award, SICE SI 2005 ベストセッション講演 賞などを受賞、システム制御情報学会, 計測自動制御学会, IEEE な どの会員.

（日本ロボット学会正会員）

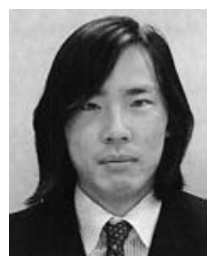

大脇 大 (Dai Owaki)

2009 年東北大学大学院工学研究科電気 · 通信工学 専攻博士後期課程修了. 同年, 同大学助教. 現在に 至る。 2007 年 2009 年 (独) 日本学術振興会特別 研究員 (DC2). 制御工学, ロボティクスに関する 研究に従事. 博士 (工学). SICE Annual Conference Young Author's Award (SICE2008), 2008 IEEE Robotics and Automation Society Japan Chapter Young Award（ICRA'08）, 計測自動制御学会システムインテグレーション 部門講演会優秀講演賞, 日本ロボット学会第 24 回研究奨励賞などを 受賞. IEEE, 計測自動制御学会の会員。（日本ロボット学会正会員）

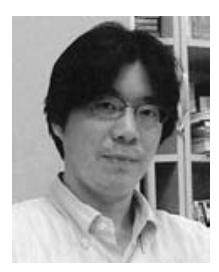

石黒章夫 (Akio Ishiguro)

1991 年名古屋大学大学院工学研究科電子機械工学専 攻博士課程後期課程修了。同年，同大学助手． 1997 年同大学大学院工学研究科計算理工学専攻助教授. 2006 年東北大学工学研究科電気・通信工学専攻教 授, 現在に至る。この間, チューリッヒ大学客員教 授。主として, 生物規範型ロボティクス, 生物シス テム論に関する研究に従事. 工学博士. 1996 日本機械学会情報・知 能 - 精密機器部門優秀講演論文賞, 2003 IEEE/RSJ International Conference on Intelligent Robots and Systems Best Paper Award Nomination Finalist, 2004 IEEE/RSJ International Conference on Intelligent Robots and Systems Best Paper Award, 2006 計 測自動制御学会システムインテグレーション部門講演会優秀講演賞, 2008 年イグ・ノーベル賞 (認知科学賞), 2008 計測自動制御学会シ ステムインテグレーション部門講演会優秀講演賞, 2009 IEEE/RSJ International Conference on Intelligent Robots and Systems Best Paper Award Nomination Finalist などを受賞. IEEE，計測自動制 御学会, 日本機械学会, 日本数理生物学会などの会員.

(日本ロボット学会正会員)

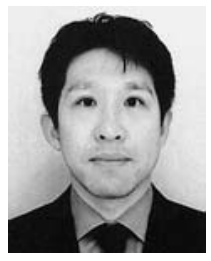

杉本靖博（Yasuhiro Sugimoto）

2002 年京都大学大学院情報学研究科修士課程修了. 2005 年同大学同研究科 博士課程修了. 同年同大学 工学研究科助手. 2008 年（株）シンクチューブ入 社. 2009 年大阪大学大学院工学研究科助教となり, 現在に至る。ロボティクス, 制御工学の研究に従事. 博士 (情報学). 第 11 回ロボティクスシンポジア 特 別奨励賞, 2006 年 日本機械学会ロボメカ部門 Robomec 表彰, 2006 年 日本ロボット学会第 21 回研究奨励賞を受賞. 計測自動制御学会, 日本機械学会などの会員.

(日本ロボット学会正会員) 